\title{
Yield of Japanese Tomato Cultivars Has Been Hampered by a Breeding Focus on Flavor
}

\author{
Tadahisa Higashide ${ }^{1}$, Ken-ichiro Yasuba, Katsumi Suzuki, \\ Akimasa Nakano, and Hiromi Ohmori \\ NARO Institute of Vegetable and Tea Science, National Agricultural and \\ Food Research Organization, Tsukuba, Ibaraki 305-8666, Japan
}

Additional index words. dry matter allocation, fruit dry matter content, soluble solids, total dry matter

\begin{abstract}
The yield of greenhouse tomatoes in Japan has not increased since the 1980s and remains much less than $30 \mathrm{~kg} \cdot \mathrm{m}^{-2}$ per year. To investigate the cause of this low yield, we compared six Japanese tomato cultivars that were commonly grown or released during the past 80 years to see whether fruit yield (fruit fresh weight per area) and dry matter (DM) content per fruit improved under current cultivation conditions. Fruit yield in 'Momotaro' (released in 1985) was lower than that in older cultivars. Total DM was determined mainly by light use efficiency and photosynthetic rate, and light use efficiency was correlated with maximum photosynthetic rate. The more modern cultivars did not show improved DM content per fruit. The DM content per fruit was strongly correlated with the soluble solids content in fruits except in 'Momotaro' and 'Momotaro colt', but soluble solids in fruits of the 'Momotaro'-type cultivars were higher than in other cultivars for a given DM content per fruit. Thus, tomato breeding in Japan appears to have focused on fruit soluble solids content per unit DM rather than fruit yield or DM content; as a result, only the former parameter has improved greatly.
\end{abstract}

The yield of greenhouse tomatoes (Solanum lycopersicum) in The Netherlands has doubled from $\approx 30 \mathrm{~kg} \cdot \mathrm{m}^{-2}$ per year in the $1980 \mathrm{~s}$ to $60 \mathrm{~kg} \cdot \mathrm{m}^{-2}$ per year in 2005 (Kwantitatieve Informatie voor de Glastuinbouw, 2005). Breeding for higher-yielding cultivars undoubtedly played a role in this yield increase: the yield of modern tomato cultivars under current cultivation conditions was $40 \%$ higher than that of old cultivars under the same conditions (Van der Ploeg et al., 2007). Higashide and Heuvelink (2009) showed that the yield increase over the past 50 years in Dutch tomatoes resulted from increased total DM production, which resulted from high light use efficiency (LUE).

In Japan, tomato is the most important crop placed in the vegetable category with the highest total value of production for many years (MAFF, 2007). However, although cultivation techniques and breeding of new cultivars have been improved in Japan, the yield of greenhouse tomatoes has not increased since the 1980 s, remaining much less than $\approx 30 \mathrm{~kg} \cdot \mathrm{m}^{-2}$ per year. Although temperatures are higher in Japanese summer than in The Netherlands, little research supports the belief that this low yield is caused by high summer temperatures. To determine the cause and to find ways to improve yield, the Super Horticulture Project was launched, and several studies have recently been conducted under it.

Received for publication 18 June 2012. Accepted for publication 13 Aug. 2012.

${ }^{1}$ To whom reprint requests should be addressed; e-mail ton@affrc.go.jp.
The factors prioritized during the breeding of Japanese cultivars might explain their low yield, because Japanese breeders have focused on improving disease and pest resistance and fruit quality. Matsuda et al. (2010) reported fruit growth rates of Dutch and Japanese cultivars under high $\mathrm{CO}_{2}$ conditions were limited by source and sink strength, respectively. The DM content per fruit of Japanese cultivars was higher than that of Dutch cultivars, although the fresh fruit yield was lower than that of modern Dutch cultivars (Higashide and Heuvelink, 2009). Yield of tomatoes (fresh weight per area) is negatively correlated with the total soluble solids (SS) content (Stevens and Rudich, 1978). In tomato processing, the DM content per fruit is one of the most important characteristics in addition to the fresh weight per area because the production of tomato concentrates and paste requires removal of water. Fresh tomato yield is determined by DM content per fruit and fruit DM. Accordingly, if Japanese breeders had improved the DM content per fruit, total DM of fruits might also increase without an increase in fresh yield. We therefore proposed that an improvement in fruit quality may have been more important for tomato breeders in Japan than developing high-yielding cultivars. Here, we compared six Japanese tomato cultivars that have been commonly grown during the past 80 years to see whether yield and DM content per fruit have improved under current cultivation conditions.

To develop high-yielding cultivars, breeders can take advantage of those developed in other countries as breeding materials. Recently,
Japanese breeders could also introduce Dutch cultivars as breeding materials. However, if high yield had been unimportant for Japanese breeders, old Japanese cultivars also might have traits responsible for high yield such as high LUE. If so, then we could use old Japanese cultivars to develop new highyielding cultivars. Thus, we also investigated the differences in yield and fruit characteristics of Japanese cultivars that have been commonly grown during the past 80 years to seek traits that could be incorporated into the breeding of high-yielding cultivars.

\section{Materials and Methods}

Relying on the data of Aoki (1998) and Sumida et al. (2008), we selected six Japanese tomato cultivars that were released and that had been commonly grown during the past 80 years: 'Sekai-ichi' (commonly used in the 1930s), 'Fukujyu 2' (1940s to the 1950s), 'Aichi fast' (1950s to the 1960s), 'Kyoryoku-beijyu' (1950s to the 1960s), 'Momotaro' (released in 1985), and 'Momotaro colt' (2003). 'Sekai-ichi' is a true-breeding cultivar; 'Fukuju 2' is one of the earliest F1 hybrids. 'Momotaro' inherited Japanese cultivars and 'Florida MH-1' and was the most popular cultivar in Japan. After release of 'Momotaro', 26 sister cultivars have been released until now and 'Momotaro colt' is one of them. We compared their fruit and other characteristics in a short-term experiment. All six cultivars are indeterminate-growth types with large, round fruits.

The seeds were sown in seed trays on 15 Jan. 2010, and $20 \mathrm{~d}$ later, the seedlings were transplanted into rockwool cubes. On $18 \mathrm{Feb}$. 2010, we transplanted the plants (60 plants per row, 2.5 plants $/ \mathrm{m}^{2}$ ) into seven rows in a rockwool system in a greenhouse compartment $(14 \mathrm{~m} \times 12 \mathrm{~m})$ at the National Agriculture and Food Research Organization Institute of Vegetable and Tea Science in Taketoyo, Japan. The temperatures at which ventilation and heating began were set at 25 and $13{ }^{\circ} \mathrm{C}$, respectively. The experiment was conducted from $18 \mathrm{Feb}$. to 20 June 2010. Otsuka-A nutrient solution (Otsuka AgriTechno, Tokyo, Japan; it consisted of 9.3 $\mathrm{mm} \mathrm{NO}^{3-}, 4.3 \mathrm{~mm} \mathrm{~K}^{+}, 4.1 \mathrm{~mm} \mathrm{Ca}^{2+}, 1.5 \mathrm{~mm}$ $\mathrm{Mg}^{2+}, 0.9 \mathrm{~mm} \mathrm{H}_{2} \mathrm{PO}_{4}^{-}, 2.7 \mathrm{mg} \cdot \mathrm{L}^{-1}$ iron, $1.2 \mathrm{mg} \cdot \mathrm{L}^{-1}$ manganese, $0.51 \mathrm{mg} \cdot \mathrm{L}^{-1}$ boron, $0.09 \mathrm{mg} \cdot \mathrm{L}^{-1}$ zinc, $0.03 \mathrm{mg} \cdot \mathrm{L}^{-1}$ copper, and $0.03 \mathrm{mg} \cdot \mathrm{L}^{-1}$ molybdenum) adjusted to 1.2 to $2.5 \mathrm{dS} \cdot \mathrm{m}^{-1}$ was provided to the plants. The interval of the nutrient solution supply was controlled based on outdoor solar radiation. The daily drain percentage was maintained at $20 \%$ to $30 \%$ of the total supply of nutrient solution. Plants were trained and leaves were pruned following standard modern Dutch practices because tomato yields are usually higher in the Dutch practices than in Japanese practices (Kanai et al., 2001; Suzuki, 2006). Flowers were pollinated by bumblebees, and the number of fruits per truss was not adjusted by pruning because fruit size in each cultivar was not decreased depending on number of fruits per truss. All plants were pinched 
above the sixth to eighth truss on 28 Apr. 2010 , when they had reached the top of the training wire. The experiment was conducted in three blocks by a complete randomized block design with two double rows per block and one border row on each side of the blocks. The spacing was $60 \mathrm{~cm}$ between rows within the double rows and $190 \mathrm{~cm}$ between double rows. We planted 20 plants per cultivar in each block (three cultivars per double row $\times$ two double rows). We planted 10 plants per cultivar in the border rows and did not measure these plants.

We harvested all mature fruits from eight plants per cultivar in each block three times a week and measured their fresh and dry weights. We also measured leaf (leaf blade + petiole) area (using a LI-3100C leaf-area meter; LI-COR, Lincoln, NE) and the fresh and dry weights of leaves, stems, and all fruits of two or four plants per cultivar per block by destructive sampling at 34, 61, and $116 \mathrm{~d}$ after transplanting. Mature and immature fruits were measured separately. To avoid the influence of this harvesting on the remaining plants and their light interception, we harvested two plants and two guard plants per cultivar per block remained in each measurement during the first two destructive samples. We also measured the SS content (percent of fresh weight) in fruits from the fourth to the seventh trusses ( $\mathrm{n}=25$ to 39 ) using a refractometer (PR-101; Atago, Tokyo, Japan).

We measured the individual-leaf maximum photosynthetic rate of mature upper leaves twice, at 54 and $55 \mathrm{~d}$ after transplanting, using one leaf from each of four plants in each cultivar per block with a portable photosynthesis system (LI-6400; LI-COR) at $1500 \mu \mathrm{mol} \cdot \mathrm{m}^{-2} \cdot \mathrm{s}^{-1}$ photosynthetic photon flux density $[P P F D$; red $(630 \mathrm{~nm})+10 \%$ blue $(470 \mathrm{~nm})$ light-emitting diodes] and at $1000 \mu \mathrm{mol} \cdot \mathrm{mol}^{-1} \mathrm{CO}_{2}$. To obtain a photosynthetic light-response curve, we chose four cultivars, Sekai-ichi, Aichi fast, Momotaro, and Momotaro colt, that covered the full range of cultivar ages, and we measured the photosynthetic rate of mature upper leaves twice using one leaf from each of two plants in each cultivar at 56 and $57 \mathrm{~d}$ after transplanting. The photosynthetic rate of the leaves was measured at light intensities of 0,10 , $20,40,60,200,300,500,800,1000$, and $1500 \mu \mathrm{mol} \cdot \mathrm{m}^{-2} \cdot \mathrm{s}^{-1}$ PPFD and the ambient $\mathrm{CO}_{2}$ level $\left(370 \mu \mathrm{mol} \cdot \mathrm{mol}^{-1}\right)$

Light extinction in the plant canopy can be described using the following equation (Monsi and Saeki, 1953):

$$
I=I_{0} \cdot \mathrm{e}^{-k \cdot L}
$$

where $I$ represents the light intensity at a given point in the plant canopy, $I_{0}$ represents the light intensity above the canopy, $k$ represents the light-extinction coefficient, and $L$ represents the cumulative leaf area index (LAI) at that point in the canopy. To obtain the light-extinction coefficient for each cultivar, we measured $P P F D$ using a 1-m-long $P P F D$ sensor (LI-191SA; LI-COR) at six different heights in the closed plant canopy of each cultivar at 67 to $69 \mathrm{~d}$ after transplanting: LAI ranged from 4.2 to 5.5 , and plant height ranged from 180 to $230 \mathrm{~cm}$. $P P F D$ above the plant canopy was also measured with a $P P F D$ sensor (LI-190SA; LICOR) and recorded using a data logger (NR600; Keyence, Tokyo, Japan). The individual leaf area of each cultivar was obtained using the following regression equation:

$$
A_{1}=a \cdot L_{1} \cdot W_{1}
$$

where $A_{1}$ represents the leaf area $\left(\mathrm{cm}^{2}\right)$, $a$ represents a proportionality factor for each cultivar (0.31, 'Sekai-ichi'; 0.38, 'Fukujyu 2'; 0.38 , 'Aichi fast'; 0.31, 'Kyoryoku beijyu'; 0.38, 'Momotaro'; 0.35, 'Momotaro colt'), $L_{1}$ represents the leaf length $(\mathrm{cm})$, and $W$ represents the leaf width $(\mathrm{cm})$. The regression equations $\left(R^{2}=0.76\right.$ to $0.90, P<0.05$ for all regressions) were obtained by destructive sampling at $61 \mathrm{~d}$ after transplanting. The cumulative LAI at each of the six heights was calculated from the individual leaf area and the number of leaves at that height. The lightextinction coefficient was obtained as the slope of a logarithmic regression of $P P F D$ against cumulative LAI at the six heights. LUE was calculated as the slope of a linear regression of the total cumulative DM production as a function of the integral intercepted photosynthetically active radiation $(P A R)$ at the three sample dates. Greenhouse transmissivity and the fraction of PAR were assumed to be $60 \%$ and $50 \%$ of global radiation, respectively (Kurata, 1994; Society of Agricultural Meteorology of Japan, 1997). Daily $P A R$ intercepted by the plants of each cultivar was calculated from LAI and the lightextinction coefficient in each cultivar.

\section{Results and Discussion}

Table 1 presents the fruit data. Fruit yields were significantly higher in 'Aichi fast' and 'Kyoryoku-beijyu' than in the more recent 'Momotaro'. Fruit yield was higher in 'Aichi fast' than in all other cultivars, and the difference was significant except for 'Kyoryokubeijyu' and 'Sekai-ichi'. Fruit numbers per truss and per plant were also significantly higher in 'Aichi fast' than in the other cultivars. Fruit numbers per truss and per plant in 'Momotaro' were significantly lower than those in the other cultivars, except for fruit number per truss between 'Momotaro' and 'Momotaro colt'. Fruit weight (per fruit) also differed significantly, being highest in 'Sekai-ichi' and 'Aichi fast' and lowest in 'Kyoryoku-beijyu' and 'Fukujyu 2'. The SS content was significantly higher in fruits of 'Momotaro colt' than in all other cultivars and was significantly lower in 'Kyoryokubeijyu' than in all other cultivars except 'Sekaiichi'. The fruit SS contents in 'Fukujyu 2' and 'Momotaro' were significantly higher than those of 'Sekai-ichi' and 'Kyoryoku-beijyu'. The DM content per fruit was significantly higher in 'Fukujyu 2' than in the other cultivars and was significantly higher in 'Aichi fast' and 'Momotaro colt' than in 'Kyoryokubeijyu' and 'Momotaro'. The negative relationship of yield and SS is well known (Stevens and Rudich, 1978). However, the SS in the newest cultivar, Momotaro colt, was higher than all other cultivars, although the yield in 'Momotaro colt' was not less than the older cultivars except 'Aichi fast' (Table 1). These results indicate that Japanese breeders almost succeeded in increasing in the SS without a decrease in the yield.

Table 2 presents the biomass data. The leaf and stem dry weights differed significantly among the cultivars. Fruit dry weight per plant was significantly lower in 'Momotaro' than in all other cultivars, although there was no significant difference among the other cultivars. Total DM production in 'Momotaro' was also significantly lower than in all other cultivars except for 'Kyoryokubeijyu'. DM allocation to the fruits was significantly higher in 'Aichi fast' than in all other cultivars except for 'Sekai-ichi' and 'Kyoryoku-beijyu', and it was significantly lower in 'Momotaro' and 'Momotaro colt' than in 'Kyoryoku-beijyu' and 'Aichi fast'.

Table 3 presents the growth and morphological data of the canopy. The light-extinction coefficient represents how steeply light is diminished by light interception of leaves with increasing depth in the canopy. This coefficient was significantly lower in 'Sekaiichi' than in all other cultivars. The coefficients in 'Aichi fast' and 'Momotaro colt' were significantly lower than those in 'Kyoryokubeijyu' and 'Fukujyu 2'. There was no difference

Table 1. Fruit yield, numbers, weight per fruit, soluble solids content, and dry matter content per fruit of six

\begin{tabular}{|c|c|c|c|c|c|c|c|}
\hline Cultivar & Period $^{\mathrm{z}}$ & $\begin{array}{l}\text { Fruit yield } \\
\left(\mathrm{kg} \cdot \mathrm{m}^{-2} \mathrm{FW}\right)\end{array}$ & $\begin{array}{l}\text { No. fruits } \\
\text { per truss }\end{array}$ & $\begin{array}{l}\text { No. fruits } \\
\text { per plant }\end{array}$ & $\begin{array}{l}\text { Fruit wt } \\
\text { (g/fruit) }\end{array}$ & $\begin{array}{l}\text { Soluble } \\
\text { solids } \\
\left({ }^{\circ} \text { Brix }\right)\end{array}$ & $\begin{array}{c}\text { Dry matter } \\
\text { content } \\
\left(\mathrm{g} \cdot \mathrm{g}^{-1}\right)\end{array}$ \\
\hline Sekai-ichi & 1930 & $11.0 \quad a b c^{x}$ & $7.9 \quad \mathrm{~d}$ & $53.1 \quad \mathrm{c}$ & $198 \mathrm{c}$ & $5.8 \quad \mathrm{ab}$ & $0.045 \mathrm{ab}$ \\
\hline Fukujyu 2 & 1940 & 9.7 & 7.4 & 50.3 & 169 & 6.2 & 0.050 \\
\hline Kyoryoku-beijyu & 1950 & 11.7 & 6.4 & 49.1 & 164 & 5.7 & 0.044 \\
\hline Aichi fast & 1950 & 12.9 & 9.6 & 66.3 & 197 & 6.0 & 0.047 \\
\hline Momotaro & 1985 & 9.2 & 4.7 & 32.6 & 186 & 6.2 & 0.044 \\
\hline Momotaro colt & 2003 & 10.5 & 5.7 & 43.8 & 170 & 6.7 & 0.048 \\
\hline
\end{tabular}
Japanese tomato cultivars at $116 \mathrm{~d}$ after transplanting.

'Period when the four old cultivars were commonly used and the year when the 'Momotaro'-type cultivars were released.

${ }^{\mathrm{y}}$ Mature only.

${ }^{\mathrm{x}}$ Values followed by different letters within a column differ significantly $(P<0.05$; analysis of variance followed by Tukey's multiple-comparison test; $n \geq 12$ ).

$\mathrm{FW}=$ fresh weight. 
in specific leaf area among the cultivars. LAI at $116 \mathrm{~d}$ after transplanting was significantly lower in 'Aichi fast' than in 'Sekai-ichi', 'Fukujyu 2', and 'Momotaro colt'. Average LAI during the experimental period was significantly lower in 'Aichi fast' than in 'Fukujyu 2' and 'Momotaro Colt'. LUE was significantly lower in 'Momotaro' than in all other cultivars except 'Kyoryoku-beijyu'. LUE was significantly higher in 'Sekai-ichi', 'Aichi fast', and 'Momotaro colt' than in the other cultivars.

The maximum photosynthetic rate per leaf measured at $1500 \mu \mathrm{mol} \cdot \mathrm{m}^{-2} \cdot \mathrm{s}^{-1}$ and $1000 \mu \mathrm{mol} \cdot \mathrm{mol}^{-1} \quad \mathrm{CO}_{2}$ was significantly lower in 'Momotaro' than in 'Momotaro colt' and 'Sekai-ichi' (data not shown). However, no other cultivars differed significantly. The photosynthetic rate per leaf was significantly lower in 'Momotaro' than in 'Sekaiichi', 'Aichi fast', and 'Momotaro colt' at almost all PPFD levels (Fig. 1).

Table 2. Leaf, stem, and fruit dry weight (DW) per plant, total dry matter production, and dry matter allocation to fruits of six Japanese tomato cultivars at $116 \mathrm{~d}$ after transplanting.

\begin{tabular}{|c|c|c|c|c|c|c|c|c|c|c|c|}
\hline \multirow{2}{*}{$\begin{array}{l}\text { Cultivar } \\
\text { Sekai-ichi }\end{array}$} & \multirow{2}{*}{$\frac{\text { Period }^{\mathrm{z}}}{1930}$} & \multicolumn{2}{|c|}{$\begin{array}{c}\text { Leaf DW } \\
\text { (g/plant) }\end{array}$} & \multicolumn{2}{|c|}{$\begin{array}{l}\text { Stem DW } \\
\text { (g/plant) }\end{array}$} & \multicolumn{2}{|c|}{$\begin{array}{c}\text { Fruit DW } \\
\text { (g/plant) }\end{array}$} & \multicolumn{2}{|c|}{$\begin{array}{l}\text { Total dry } \\
\text { matter } \\
\left(\mathrm{g} \cdot \mathrm{m}^{-2}\right)\end{array}$} & \multicolumn{2}{|c|}{$\begin{array}{l}\text { Dry matter } \\
\text { allocation to } \\
\text { the fruits } \\
\left(\mathrm{g} \cdot \mathrm{g}^{-1}\right)\end{array}$} \\
\hline & & 147 & $b c^{y}$ & 87 & $a b$ & 291 & $\mathrm{~b}$ & 1267 & $\mathrm{~b}$ & 0.57 & $a b c$ \\
\hline Fukujyu 2 & 1940 & 147 & $b c$ & 81 & $a b$ & 286 & b & 1260 & b & 0.56 & $a b$ \\
\hline Kyoryoku-beijyu & 1950 & 118 & $a b$ & 70 & $a$ & 283 & b & 1164 & $a b$ & 0.60 & $b c$ \\
\hline Aichi fast & 1950 & 112 & $a$ & 75 & $a$ & 313 & $\mathrm{~b}$ & 1237 & $\mathrm{~b}$ & 0.63 & $c$ \\
\hline Momotaro & 1985 & 129 & $a b c$ & 69 & $a$ & 217 & $\mathrm{a}$ & 1026 & $\mathrm{a}$ & 0.52 & $a$ \\
\hline Momotaro colt & 2003 & 153 & $c$ & 104 & $b$ & 274 & b & 1311 & $\mathrm{~b}$ & 0.52 & $a$ \\
\hline
\end{tabular}

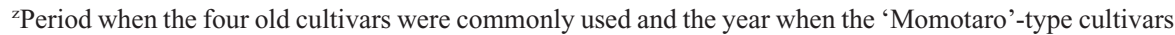
were released.

${ }^{y}$ Values followed by different letters within a column differ significantly $(P<0.05$; analysis of variance followed by Tukey's or Dunn's multiple-comparison test; $\mathrm{n}=12$ ).

'Including immature fruits.

Table 3. Light-extinction coefficient at 67 to $69 \mathrm{~d}$ after transplanting of six Japanese tomato cultivars, specific leaf area (SLA) and leaf area index (LAI) at $116 \mathrm{~d}$ after transplanting, and average LAI and light-use efficiency (LUE) during the experiment.

\begin{tabular}{|c|c|c|c|c|c|c|c|c|c|c|}
\hline \multirow{2}{*}{$\frac{\text { Cultivar }}{\text { Sekai-ichi }}$} & \multirow{2}{*}{$\frac{\text { Period }^{\mathrm{z}}}{1930}$} & \multicolumn{2}{|c|}{$\begin{array}{l}\text { Light-extinction } \\
\text { coefficient }\end{array}$} & \multicolumn{2}{|c|}{$\begin{array}{c}\text { SLA } \\
\left(\mathrm{m}^{2} \cdot \mathrm{g}^{-1}\right)\end{array}$} & \multicolumn{2}{|c|}{$\begin{array}{c}\text { LAI } \\
\left(\mathrm{m}^{2} \cdot \mathrm{m}^{-2}\right)\end{array}$} & $\begin{array}{l}\text { Avg LAI } \\
\left(\mathrm{m}^{2} \cdot \mathrm{m}^{-2}\right)\end{array}$ & \multicolumn{2}{|c|}{$\begin{array}{c}\mathrm{LUE} \\
\left(\mathrm{g} \cdot \mathrm{MJ}^{-1}\right)\end{array}$} \\
\hline & & 0.69 & $a^{\mathrm{y}}$ & 0.016 & $a$ & 5.9 & bc & $3.3 \mathrm{ab}$ & 3.1 & $c$ \\
\hline Fukujyu 2 & 1940 & 0.83 & $c d$ & 0.018 & $\mathrm{a}$ & 6.3 & c & 3.4 & 2.9 & $b$ \\
\hline Kyoryoku-beijyu & 1950 & 0.89 & $d$ & 0.017 & $\mathrm{a}$ & 4.9 & $\mathrm{ab}$ & 2.8 & 2.7 & $a b$ \\
\hline Aichi fast & 1950 & 0.74 & $b$ & 0.016 & $\mathrm{a}$ & 4.5 & $\mathrm{a}$ & 2.7 & 3.1 & $c$ \\
\hline Momotaro & 1985 & 0.75 & $b c$ & 0.016 & $\mathrm{a}$ & 5.1 & $\mathrm{ab}$ & 3.2 & 2.4 & $a$ \\
\hline Momotaro colt & 2003 & 0.76 & $b$ & 0.017 & $\mathrm{a}$ & 6.3 & c & 3.5 & 3.1 & $c$ \\
\hline
\end{tabular}

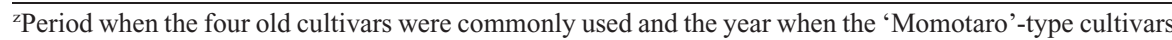
were released.

${ }^{y}$ Values followed by different letters within a column differ significantly $(P<0.05$; analysis of variance followed by Tukey's multiple-comparison test in roman type or $95 \%$ confidence intervals in italics; $n=12$ ).

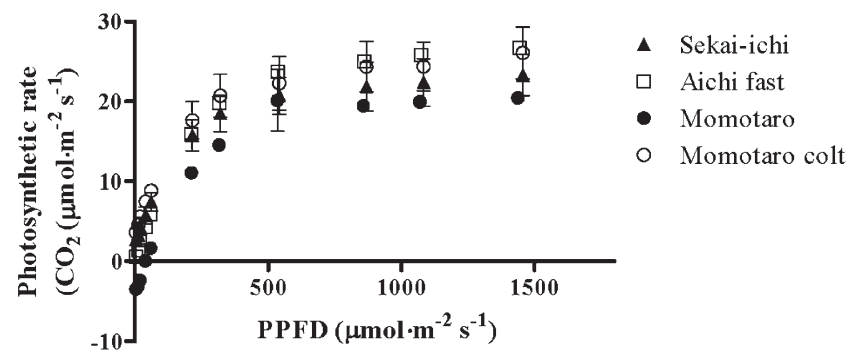

Fig. 1. Photosynthetic light-response curves for individual leaves of four Japanese tomato cultivars. Values are means $\pm \operatorname{sDs}(n=4$ to 8$)$. the period when a cultivar was commonly used and any of the other yield and fruit characteristics (data not shown). These results suggest that tomato breeders in Japan have not attempted to develop improved high-yielding cultivars and have not focused on specific characteristics such as total DM production and its allocation to the fruits.

Table 4 shows the correlations between the yield components and the growth and photosynthetic characteristics. Fresh fruit yield was significantly positively correlated with the fruit dry weight per area, although there was no significant correlation between fresh fruit yield and the DM content per fruit. Accordingly, the difference in fresh fruit yield among the cultivars is mainly explained by the difference in fruit dry weight per area rather than the DM content per fruit. Dry weight yield per area may be determined by the total DM and by the DM allocation to the fruits. There was no significant correlation between fruit dry weight per area and total DM or its allocation to the fruits $(P=0.078$ and 0.094 , respectively). Total DM was strongly and significantly positively correlated with LUE and maximum photosynthetic rate but not with the fraction of intercepted light. LUE was significantly correlated with the maximum photosynthetic rate but not with LAI or the light-extinction coefficient. The difference in LUE among cultivars therefore is mainly explained by the difference in leaf photosynthetic rate. DM allocation to the fruits was significantly correlated with the number of fruits per plant $(r=0.84)$ and per truss (data not shown). There was no correlation between DM allocation to the fruits and fruit weight per fruit (data not shown). Thus, the difference in DM allocation to the fruits is explained by the difference in the number of fruits. DM allocation to the fruits was significantly negatively correlated with LAI. This suggests that DM allocation to the fruits restricted the growth of the leaf area.

The lack of any significant correlation between the period when a cultivar was commonly used and the DM content per fruit suggests that breeding for the latter parameter was not a goal of Japanese breeders. There was no correlation between the DM content per fruit and the SS content of the fruits of all six cultivars combined, but there was a strong and significant positive correlation when 'Momotaro' and 'Momotaro colt' were excluded (Fig. 2). The SS content in fruits of 'Momotaro' and 'Momotaro colt' were much higher than the values predicted by the regression for the four other cultivars. Because low DM content indicates high water content, the low DM content and high SS in 'Momotaro colt' accordingly implied juicy and sweet fruits. Although there is generally a correlation between the DM content per fruit and the SS content in tomatoes, Kawabata et al. (2002) observed that changes in the SS concentration were inconsistent with changes in DM content per fruit under conditions that restricted growth: the carbohydrates transported to the fruits were preferentially allocated to SS rather than insoluble carbohydrates. We 
Table 4. Correlations (Pearson's $r$ coefficient) between the yield components and the growth and photosynthetic characteristics of six Japanese tomato cultivars released in different years. ${ }^{\mathrm{z}}$

\begin{tabular}{lccccccccc}
\hline & YFW & YDW & FDMC & TDM & FF & LUE & FLI & LEC & PR \\
\hline YDW & $0.90^{*}$ & - & - & - & - & - & - & - & \\
FDMC & 0.02 & 0.35 & - & - & - & - & - & - & \\
TDM & 0.49 & 0.76 & 0.67 & - & - & - & - & - & \\
FF & $0.87^{*}$ & 0.74 & -0.12 & 0.13 & - & - & - & - & \\
LUE & 0.55 & $0.82^{*}$ & 0.54 & $0.96^{* *}$ & 0.24 & - & - & - & \\
FLI & -0.42 & -0.57 & -0.05 & -0.26 & -0.53 & -0.51 & - & - & \\
LEC & 0.28 & 0.36 & 0.59 & 0.15 & 0.42 & 0.18 & -0.42 & - & \\
PR & 0.35 & 0.60 & 0.51 & $0.95^{* *}$ & -0.08 & $0.89^{*}$ & -0.10 & -0.14 & \\
LAI & -0.64 & -0.36 & 0.37 & 0.29 & $-0.85^{*}$ & 0.16 & 0.41 & -0.46 & 0.47 \\
NF & $0.86^{*}$ & $0.95^{* *}$ & 0.30 & 0.57 & $0.84^{*}$ & 0.68 & -0.74 & 0.56 & 0.34 \\
\hline
\end{tabular}

${ }^{2} \mathrm{YFW}=$ yield of fruit (fresh weight per area); YDW = yield of fruit (dry weight per area); FDMC = dry matter content per fruit; TDM = total dry matter (above the ground); $\mathrm{FF}=$ fraction of dry matter allocated to fruits; LUE = light-use efficiency; FLI = fraction of light intercepted; LEC = light-extinction coefficient; $\mathrm{PR}=$ photosynthetic rate (maximum); LAI = leaf area index (average during the experimental period); $\mathrm{NF}=$ number of fruits per plant.

* and ** indicate a significant correlation at $P<0.05$ and $P<0.01$, respectively $(\mathrm{n}=6)$.

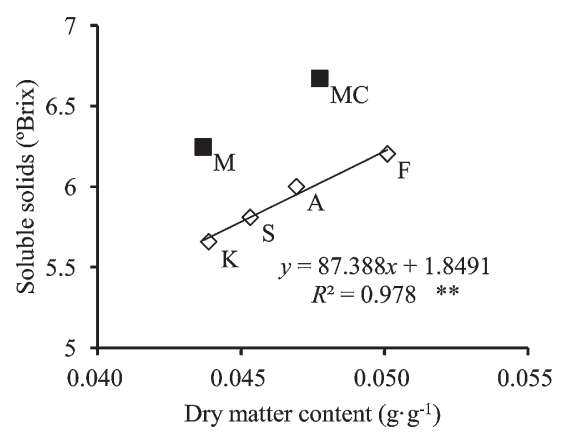

Fig. 2. Relation between the dry matter content per fruit and the soluble solids content in fruits of six Japanese tomato cultivars. The regression line excludes 'Momotaro' and 'Momotaro colt'. $\mathrm{S}=$ 'Sekai-ichi'; $\mathrm{F}=$ 'Fukujyu 2'; $\mathrm{A}=$ 'Aichi fast'; K = 'Kyoryoku-beijyu'; $\mathrm{M}=$ = 'Momotaro'; $\mathrm{MC}=$ 'Momotaro colt'.

hypothesize that the SS contents in the fruits of 'Momotaro' and 'Momotaro colt' were higher than those in the other cultivars under conditions with no restriction of fruit growth and that the contents of insoluble carbohydrates were lower or water contents were higher than in the other cultivars. This suggests that the nutrient composition and palatability of tomato fruits changed after the development of 'Momotaro'. Although Brix reflects fruit quality as SS including sugars, organic acids, soluble nitrogen compounds, or minerals, fruit quality is determined by several factors such as firmness. The sugar/ acid ratio is also an important indicator of fruit flavor, although we did not measure titratable acid. Detailed investigations will be required to confirm this change in fruit quality.

The low yield of 'Momotaro' was caused by both a low total DM production and a low DM allocation to fruits (Table 2). These parameters were caused by both a low LUE (Table 3 ) and a low fruit number (Table 1).
Because the total DM was strongly correlated with LUE and photosynthetic rate (Table 4), like in Dutch cultivars (Higashide and Heuvelink, 2009), then breeders who want to develop high-yielding Japanese cultivars should select cultivars with a high LUE. High DM allocation to the fruits may also improve yield. Among the six cultivars we tested, 'Aichi fast' seems likely to have traits that might be used in breeding for high yield, because it had higher LUE (Table 3) and DM allocation to fruits (Table 2) than the other cultivars. However, it is not easy to measure LUE in a large segregating population. If a molecular marker linked to LUE can be found, the breeders could use them to improve highyielding cultivars. We do not recommend trying to improve the increase DM allocation to the fruits more than 'Aichi fast', because increasing DM allocation to the fruits will decrease LAI (based on the negative correlation between the two parameters; Table 4), and this may decrease whole-plant photosynthesis sufficiently to decrease fruit yield.

We conclude that high-yielding cultivars have not been a priority for Japanese tomato breeders. Similarly, breeders have not tried to improve the DM content per fruit. However, the SS content per unit of DM content has increased in 'Momotaro' (released in 1985) and further in 'Momotaro colt' (released in 2003) compared with several of the older cultivars, which suggests that Japanese breeders have improved fruit quality. We believe that Japanese consumers and retailers have demanded improvements in fruit taste more strongly than in yield, and Japanese breeders have therefore focused on fruit quality such as SS rather than quantity.

\section{Literature Cited}

Aoki, H. 1998. Change in tomato cultivars. Tomato physiology and cultivation techniques. SeibundoShinkosha, Tokyo, Japan [in Japanese].
Higashide, T. and E. Heuvelink. 2009. Physiological and morphological changes over the past 50 years in yield components in tomato. J. Amer. Soc. Hort. Sci. 134:460-465.

Kanai, Y., H. Abe, H. Ishizuka, and K. Shimizu 2001. Development of Gunma horticultural experiment station-type high wire training system for labor-saving of tomato culture in greenhouse. Res. Bul. Gunma Hort. Exp. Stn. 6:1-6 [in Japanese].

Kawabata, S., S.H. Han, and R. Sakiyama. 2002. Effect of mechanically restricting tomato fruit enlargement on the partitioning of soluble sugars. J. Jpn. Soc. Hort. Sci. 71:480-484.

Kurata, K. 1994. Light environmental control, p. 233-242. In: Nishi, S., M. Amano, T. Itagi, T. Ito, I. Ueno, S. Okitsu, I. Kurata, T. Kozai, Y. Odaka, R. Sakiyama, K. Seike, T. Takakura, H. Hakura, and T. Murai (eds.). Greenhouse horticulture handbook. 3rd Ed. Japanese Greenhouse Horticulture Association, Tokyo, Japan [in Japanese].

Kwantitatieve Informatie voor de Glastuinbouw. 2005. Proefstation voor de bloemistrij en glasgroente (PGB). Kwantitatieve Informatie voor de Glastuinbouw, Wageningen, The Netherlands.

MAFF. 2007. Survey of vegetables production and shipments, Crop survey. Ministry of Agriculture Forestry and Fisheries of Japan, Tokyo, Japan.

Matsuda, R., A. Nakano, D. Ahn, K. Suzuki, K. Yasuba, and M. Takaichi. 2010. Growth characteristic and sink strength of fruit at different $\mathrm{CO}_{2}$ concentrations in a Japanese and a Dutch tomato cultivar. Sci. Hort. 127:520-527.

Monsi, M. and T. Saeki. 1953. Über den Lichtfaktor in den Pflanzengesellschaften und seine Bedeutung für die Stoffproduction. Jpn. J. Bot 14:22-52 (On the Factor Light in Plant Communities and its Importance for Matter Production. Ann. Bot. (Lond.) 95:549-567.

Society of Agricultural Meteorology of Japan. 1997. Micrometeorological phenomena, p. 81-109. In: Maki, T., S. Iwata, Z. Uchijima, T. Oikawa, K. Omasa, K. Kurata, T. Kozai, E. Goto, H. Kon, I. Nouchi, Y. Harazono, T. Hoshi, H. Honjo, and S. Yamakawa (eds.). Agricultural meteorology glossary. Society of Agricultural Meteorology of Japan, Tokyo, Japan [in Japanese].

Stevens, M.A. 1994. Processing tomato breeding in the 90's: A union of traditional and molecular techniques. Acta Hort. 487:23-34.

Stevens, M.A. and J. Rudich. 1978. Genetic potential for overcoming physiological limitation on adaptability, yield and quality in the tomato. HortScience 13:673-678.

Sumida, A, T. Kaya, and M. Hatanaka. 2008. Breeding and promotion of tomato cultivar 'Momotaro' resulted from innovation of its shipping and taste. Hort. Res. (Japan) 7:1-4. [in Japanese].

Suzuki, K. 2006. Tomato production in high-eaved greenhouses. Proc. of Vegetable and Tea Science 3:73-77 [in Japanese].

Van der Ploeg, A., M. van der Meer, and E. Heuvelink. 2007. Breeding for more energy efficient greenhouse tomato: Past and future perspectives. Euphytica 158:129-138.

Zamir, D., S. Grandillo, and S.D. Tanksley. 1999. Genes from wild species for the improvement of yield and quality of processing tomatoes. Acta Hort. 487:285-288. 